\title{
Erratum to: Trusted Information
}

\author{
Michel Dupuy ${ }^{1}$ and Pierre Paradinas ${ }^{2}$ \\ 1 SGDN/DCSSI/CERTA, France \\ 2 Gemplus Labs, France
}

\section{Erratum to: \\ M. Dupuy and P. Paradinas (Eds.) \\ Trusted Information \\ DOI: $10.1007 / 978-0-306-46998-5$}

The book was inadvertently published with an incorrect name of the copyright holder. The name of the copyright holder for this book is: (c) IFIP International Federation for Information Processing. The book has been updated with the changes. 